Special Issue on Violence against Individuals and Communities; Reflecting on the Trayvon Martin Case [This article appears in the Narratives and Reflections section of the Special Issue]

\title{
Bearing Black
}

\section{Deanne Bell, Ph.D.}

\begin{abstract}
In this essay I critically examine the idea of race in light of the killing of Trayvon Martin, an African-American unarmed teenager, in Florida in February 2012. I utilize ideas from liberation psychology, including psychic colonization, and depth psychology, including cultural complex, to explore the racialized black as a colonized, traumatized other. I also use my autoethnographic experience (as a Jamaican who now lives in the United States) to discuss how identities built on race are a source of suffering both when we make others black and when we are made black. Bearing black robs us of the possibility of our humanity. Throughout, I ask several questions about sustaining race as a sociological idea if we truly intend to dismantle racism. I invite us to reconsider race in light of an instance where Rastafarians, a small group of Afro-Jamaicans who express profound race consciousness, determine their own image, not only as black, and as a form of resisting white supremacy.
\end{abstract}

Keywords. Trayvon Martin, race, psychic colonization, cultural complex, cultural resistance 
The concept of "race" itself, the division of humanity into groups who can be defined by appearance, is only an idea, but has come to be perhaps the most powerful in its implications that the human mind has ever conceived.

- Helen Morgan (2004, p. 215)

The murder of Trayvon Martin, an African-American unarmed teenager in Florida in February 2012 , is resurfacing public conversations about racism in America. In progressive social spaces we openly discuss barbarities racism inflicts on its victims. And slowly, we are allowing its suffering to speak. But the idea of abolishing race, the warrant of racism, remains taboo in our sociological imagination. Attempts to critique racism and dismantle its apparatus of injustice while leaving the idea of race untroubled is a literal response, tied to the cultural surface. It asks only that harmful behavior be stopped; it does not demand its root be destroyed. In this essay, I explore some of the psychological consequences of racism and race as a way of questioning the role race plays in our lives.

To be made black is a form of colonization. Black is the production of an object in which a lesser value, a greater inferiority, and distinct disadvantages are ascribed based on skin color, enforced by domination. Its historical roots contain memories of human rights atrocities that include slavery, indentured servitude, and sociopolitical systems built on a caste hierarchy of subjugation. To be called black, even by oneself in the esprit de corps of the liberation movement, is to align with these barbarisms because the word black includes them, cannot escape them, even if people of color use the term to affirm pride, value, and freedom. The cultural term black was originally the chosen nomenclature of the oppressor; it is "the color of evil" (Fanon, 1986, p. 197). Attempts to reinvent black in order to neutralize its negativity in terms of racial supremacy and recast it with equivalence are futile because whiteness determines black (Hillman, 1986). And black will forever be opposite to white, which is considered supreme. Additions to the meaning of black, valuable though they may be, are therefore impotent and insufficient to eliminate the scourge its legacy elicits.

I started off brown. More accurately, I was born in Jamaica and, based on my mixed race heritage and social class, am characterized there as a "browning." In Jamaica, social class distinctions include skin color and other physical features. Biographical markers bearing evidence of white blood grant superior status resulting in greater access to wealth, education, occupation, income, legal protection, and social mobility. When I came to the United States, I was made black. My awareness, when I am in Jamaica as a privileged browning, becoming an inferiorized black woman when I am in the United States, leads me to question a shifting sense of self as a consequence of being raced. It raises several questions. Under what conditions does a human being wish to be made black? How do I understand the ignominy of being black? In living a contradiction, as a member of the oppressor class in Jamaica and the oppressed class in the United States, I experience inhumanity in both making others black and being made black. Both social locations are situated in suffering since the oppressor pays a price and the oppressed bears the cost of oppression. Both are robbed of the possibility of our humanity. Why, then, do we continue to endure social systems built upon race? Why do we bear black at the expense of our humanity? And, also, what does it mean to announce ourselves as antiracist yet sustain the very idea of race? What would be the purpose of race in a post-racist world? 
Black is traumatic. The force of racism is to physically and psychically destroy the individual-to dehumanize and deindividuate (Oliver, 2004). Once individuals are estranged from their affects, the ability to create meaning is compromised. Psychic colonization, American philosopher and psychoanalytic social theorist Kelly Oliver explains, works by excluding the individual (through the stereotype of racism), by silencing the individual (by severing their connection to their subjectivity), and by creating the colonized individual as an incapable being (by injecting inferiority into seized psychic space). The resulting "affects of oppression-depression, shame, anger and alienation-are pathologized as individual or group sickness or even as evil" (Oliver, 2004 , p. 87). These pathologies, internalized as belonging to the oppressed, further compound the effects of colonization.

In this light, black can be seen as a cultural complex which "does not express the self, but rather the self the culture would like to impose on its members" (Beebe, 2004, p. 234), with the result that "the cultural complex oppresses the self" (Beebe, p. 234). We who are made black are accosted by the collective in which we are surreptitiously invited to collude with white imposition and black capitulation (both components of the cultural complex). It is only when we begin to extricate our subjectivity differently that understanding the psychological experience of black becomes a possibility.

The purpose of thinking about the colored person's identity in terms other than appearance is not an attempt at a shortcut but, rather, resists the appearance of a reconciliation of race relations based on a false harmony. Reconsidering race involves contemplating several questions, for which easy answers are unknown to me: How can change be made not only in the material conditions (as improved by affirmative action) but the ideas that affect the person of color? What are different relational coordinates, beyond the black/white ${ }^{1}$ pole, that would dismantle race trauma? What are psychological and philosophical conditions that would utterly destroy racism?

In Jamaica's recent history a social movement developed in which a small group of black people moved away from bearing black toward the creation of a humanist society. The experience of a repressed society, formed by social, political, and economic exploitations of black Jamaicans, thwarted the development of a national consciousness capable of decolonizing Jamaica after it gained independence from Britain's colonial rule. Some Afro-Jamaicans, conscious of such alienation, opted to determine their own image. Transforming their personality in order to maintain their humanity, conscious Afro-Jamaicans became Rastafarians as a form of resisting white culture (Campbell, 1985). This marked a renewal in the struggle for emancipation from colonial impositions in Jamaica. Adherents to Rastafari philosophy offered an alternative to psychic colonization, expressing a profound race consciousness in their bid for radical social transformation. But they did not define themselves only as black. They did not imagine the possibility of their freedom emanating from within colonial ideology built on the idea of race.

Rastas, through the reggae medium, disseminate their ideas and inspiration for a new antiracist social order. Bob Marley's music, in particular, epitomizes resistance and non-violent revolt, raising consciousness about universal forms of oppression (Campbell, 1985). According to Jason Toynbee (2007), Marley's most significant contribution to changing the world order is his conception of a post-racial identity. Marley proposed that what needed to be dismantled was

\footnotetext{
${ }^{1}$ I believe we should also include brown and yellow as relevant race relational coordinates but given Trayvon Martin's and my race, for the purpose of this essay, I limit the discussion to black/white.
} 
not merely racism, but the idea of race itself. Throughout his music, embodied in his performances, is the imperative of humanism brought about by a transracial condition, imagined as genuine unity and post white supremacy.

If we believe race played a role in Trayvon Martin's death and in the slow pace of justice in investigating his murder, and acknowledge the repetition of this pattern in the United States, then perhaps it is time we question and resist not only the effects of racism but the very idea that begets it.

Contact information:

Deanne Bell, Ph.D.

Email: deannembell@gmail.com

\section{References}

Beebe, J. (2004). A clinical encounter with a cultural encounter. In T. Singer \& L. Kimbles (Eds.), The cultural complex: Contemporary Jungian perspectives on psyche and society (pp. 223-236). New York, NY: Brunner-Routledge.

Campbell, H. (2007). Rasta and resistance: From Marcus Garvey to Walter Rodney. London, England: Hansib.

Fanon, F. (1986). Black skin, white masks. London, England: Pluto Press.

Hillman, J. (1986). Notes on white supremacy: Essaying an archetypal account of historical events. Spring, 46, 29-58.

Morgan, H. (2004). Exploring racism: A clinical example of a cultural complex. In T. Singer \& L. Kimbles (Eds.), The cultural complex: Contemporary Jungian perspectives on psyche and society (pp. 212-222). New York, NY: Brunner-Routledge.

Oliver, K. (2004). The colonization of psychic space. Minneapolis, MN: University of Minnesota Press.

Toynbee, J. (2007). Bob Marley: Herald of a postcolonial world? London, England: Polity. 